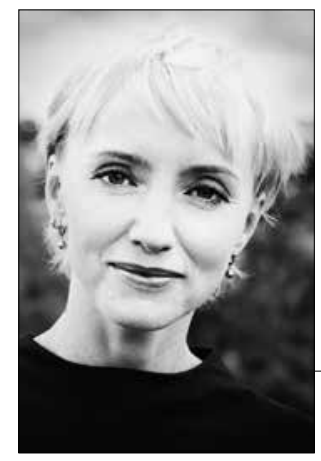

https://doi.org/10.24101/logos.2017.19

\title{
GILIJA ŽUKAUSKIENÉ
}

Lietuvos estetikų asociacija

Lithuanian Association of Aesthetics

\section{SOCIOKULTÜRINÉS BENDRUMO TARP ŽMOGAUS IR GYVŪNO PAIEŠKOS: KINETINIS ATIDUMAS IR DIALOGAS}

\author{
Looking for Socio-cultural Affinity between Human \\ and Animal: Kinetic Attentiveness and Dialogue
}

\begin{abstract}
SUMMARY
This article brings together dialogical approach offered by Josephine Donovan and Donna Haraway's notion of kinship with the organic and genealogical unity of all living creatures. This allows one to focus on the social dimension in the reformulation of the human - animal split and on the role of socio-cultural practices for the human - animal coexistence. After discussing Gilbert Simondon's concept of individuation in the human - animal relations, I extend Haraway understanding of kinship. My argument is that kinship is not a "given" phenomenon but the result of communal actions, which shows interspecific connectivity. The article analyzes socio-cultural practices as the institutes of embodied non-verbal social/ ethical contract between man and animal. Dance as an example of a socio-cultural practice shows assimilation of human-animal kinship through movement and passage in space. Contemporary dance may be viewed as an example of "liveliness" common for all species in an aesthetic way and thus may contribute to interspecies dialogue.
\end{abstract}

\section{SANTRAUKA}

Remiantis Josephine Donovan pasiūlyta dialogine prieiga nagrinèjant žmogaus - gyvūno santykius bei Donna Haraway giminingumo, siejamo ne su šeima ar kilme, bet su visų gyvų būtybių organiniu ir geneologiniu bendrumu, samprata, straipsnyje apsvarstomas socialinis aspektas performuluojant žmogaus - gyvūno perskyrą bei sociokultūrinių praktikų reikšmė tarprūšiniam sugyvenimui. Haraway giminingumo supratimas papildomas teiginiu, kad giminingumas nėra "duotybe்", bet yra rezultatas tarprūšinį susietumą suvokiančios ir „išpildančios“ bendruomenès veiksmų. Straipsnyje analizuojamos sociokultūrinès praktikos, 
kurias galima traktuoti kaip įkūnytus ne žodžiais išreikšto socialinio / etinio kontrakto tarp žmogaus ir gyvūno institutus. Ypatingas dèmesys kreipiamas ị šokị - meną, estetizuojantį rūšims bendrą "gyvumą", praeityje prisidèjusį ir ateityje galintị prisidèti prie tarprūšinio dialogo skatinimo.

\section{IVADAS}

Pagrindinis antropocentrizmo kritiku bruožas - dėmesys kūnui(-ams) ir jo(-ų) aplinkai bei jų tarpusavio sąveikai. Žvelgdami iš skirtingų laiko perspektyvu ar akcentuodami skirtingas praktikas, kuriomis šios sąveikos (issi)veikia, ivairių sričiu mokslininkai(-ès) - antropologai(-ès), envaironmentalistai(-ès), kūno, gyvūnų, feministiniu studijų atstovai(-ès), filosofai(-ès) ir teologai(-ès) siekia sugriauti specieizmo pamatus bei pateikti filosofines darnaus tarprūšinio koegzistavimo vizijas.

Straipsnį apie sociokultūrines bendrumo tarp žmogaus ir gyvūno paieškas pradèsiu nuo pagrindinių tarprūšinio koegzistavimo vizijų aptarimo. Ivade apžvelgsiu, kaip šiuolaikiniuose moksliniuose diskursuose kalbama apie socialinius žmogaus - gyvūno santykius. Telksiuosi į dialogo ir giminingumo sąvoku interpretacijas, pagrindžiančias mano pasirinktos problematikos relevantiškumą. Kitą poskyri skirsiu Gilberto Simondono geneologiškai atstatomo funkcinio paralelizmo tarp žmogaus ir gyvūno bei rūšinio susietumo nagrinèjimui ir šiame kontekste pristatomos individuacijos sąvokos aptarimui. Individuacijos kaip dinaminio interakcinio proceso apsvarstymus toliau plètosiu dviem kryptimis - viename poskyryje pateiksiu tradicinès visuomenès sociokultūrinių tarprūšinio sugyvenimo praktiku pavyzdžius; kitame - pristatysiu meno teorijas, meną kildinančias iš gyvūniškos egzistencijos, nurodydama, kaip jos gali pasitarnauti siekiant sureikšminti kūnų kalbos homologiškumu gristas sociokultūrines šokio praktikas. Pateiksiu konkrečius pavyzdžius, padedančius atsakyti i straipsnyje keliamą pagrindinį klausimą kaip gali būti išgyvenamas žmogaus - gyvūno susietumas ir kokiais praktiniais veiksmais gali būti kuriami tarprūšiniai santykiai. Teigsiu, kad sociokultūrinès judesio ir šokio praktikos, estetizuojančios tarprūšinès sąveikos dinamiškumą ir rūšims bendrą "gyvumą", gali ypatingu būdu prisidèti prie tarprūšinio dialogo skatinimo ir etiškesnių santykių (at)kūrimo.

Tarprūšinio sugyvenimo klausimą nagrinèti pradėsiu nuo Josephine Donovan pasiūlytos dialoginès prieigos žmogaus - gyvūno santykiams nagrinèti. Dialogas - labai svarbus Carol Gilligan feministinès rūpesčio etikos aspektas. Teorijos autorei tai buvo nepamainomas tyrimu metodas ir bendradarbiavimo būdas, suteikiantis galimybę išvengti itvirtintu padalijimu, išgirsti dalyvių patirtis ir kurti ilgainiui situaciją transformuojančius santykius su kitu asmeniu ${ }^{1}$. Juk kas, jei ne feministès (daugumoje moterys), gali geriau atpažinti jausma, kai asmeninè arba grupès nuomonè ignoruojama, menkinama ir laikoma nesvarbia. Tokia patirtis skatino feministes jautriai pažvelgti i kitų marginalizuoja- 
mu grupiu patirtị ir i sunkumo būti išgirstoms faktą. Donovan prie tokių marginalizuojamu grupiu priskiria gyvūnus ir dialoginę prieigą siūlo taikyti žmogaus - gyvūno santykiams nagrinèti. „Dialogo teorija reiškia mokymąsi pamatyti, ką žmogiški ideologiniai konstruktai nutyli, suvokti ir perprasti ju neaptiktus ir nepripažintus dalykus, trumpai tariant - emociškai ir intelektualiai siekti to, kas yra skirtinga, nei aš, o ne (gyvūnų atveju) performuluoti tą skirtumą kad jis atitiktų mano žmogiškumu pagrịstą išankstinį supratimą. ${ }^{.2}$

Tačiau kaip įmanoma neprimesti gyvūnams savo monologinio "aiškumo"? Jau vien tai, kad moraliné problema rūpesčio etikoje buvo pradèta sieti su rūpesčio veiksmu, o ne su teisių bei taisyklių žinojimu, leidžia moralumą suvokti kaip kontekstualų ir naratyvinį mąstymo būdą (o ne abstraktų ir formalų). Besivaržančiu teisių diskursui Gilligan priešina mąstymą apie konfliktuojančias atsakomybes ${ }^{3}$. Toks mąstymo būdas neatsiejamas nuo gailestingumo praktiku, kurios, daugelio feministinès rūpesčio gyvūnais teorijos šalininkių nuomone, yra išmokstamas dalykas ${ }^{4}$.

Akcentuodama dialogo svarbą rūpesčio gyvūnais etikoje, Donovan pasiūlo ir savitą jo supratimą. Rūpesti gyvūnijos gerove ji kviečia praplèsti susirūpinimu, „ką gyvūnai mums nori pasakyti“" ${ }^{\prime 5}$. Toks susirūpinimas (pagrịstas dialoginès etikos postulatu, kad visos gyvos būtybès nori gyventi, mégsta malonumus ir neapkenčia skausmo) priima domèn gyvūnų kūno kalbą kaip abipusiškai suprantamą jų interesų raišką. Atkreipdama dèmesi i gyvūnų kūno kalbos homolo- giškumą žmogiškam elgesiui, autorè nemato priežasčiu kodèl nereikètų rimtai atsižvelgti i aiškiai komunikuojamus gyvūnų norus ir neįtraukti ju pozicijos kaip dialoginio dèmens i žmogiškų etinių srendimų darymo procesus ${ }^{6}$, kurie galiausiai ir nulemia žmonių bei gyvūnų gyvenimo sąlygas.

Žmogaus ir gyvūno santykiai - svarbi D. Haraway tyrinèjimų tema. Panašiai kaip ir Donovan, ši autore teigia, kad rūpestis, atsakomybès prisiemimas nèra etinès abstrakcijos, bet tarpusavio mainu rezultatas, susilietimo ir demesingumo (paisymo) pasekmè $\dot{e}^{7}$. Tačiau bendrumą tarp žmonijos ir gyvūnijos Haraway mato ne vien biologiniame panašume ir bendrame troškime gyventi, bet tame, kad esame vieni kitiems gyvybiškai reikalingi. Būtent šis reikalingumas ir nulèmè ypatingus tarprūšinius santykius. Giminystę, kuri nèra susijusi su žmogiška gimine ar kilme, Haraway mato rūpesčio etikos epicentru. Ji teigia, kad mūsu rūpesčio praktikos turi orientuotis i rūšinius asambliažus, o ne i̇ atskiras rūšis, ir turi būti grịstos supratimu, kad visi Žemès gyventojai yra giminaičiai giliausia šio žodžio prasme ${ }^{8}$.

Haraway raginimas palikti mąstyma, apsiribojanti šeima ir genais, ir atsiverti neiprastumui bei šiurpą keliančiam nesuprantamumui yra kvietimas i aktyvu dialogą. Netgi patị rūpestị autore traktuoja kaip supratimą transformuojančią patirti. Tai - atsidavimas nerimą keliančiai smalsumo pareigai, kuri reikalauja, kad dienos pabaigoje žinotume daugiau, nei tos pačios dienos pradžioje ${ }^{9}$. Autoré ragina sutelkti jẻgas nebe i̇ savo žmogiškos giminės pratęsimą ir išsaugojimą, bet 
ì tarprūšinio giminingumo puoselëjimą. Tai, anot Haraway, reikalauja ne mažiau emociniu, intelektualių, meninių pastangu, individualaus ir kolektyvinio politinio kūrybiškumo.

„Rūšys kompanionès" - Haraway pasirinktas žodžių junginys, apibūdinantis žmonijos ir gyvūnijos tarpusavio priklausomybę ir kartu legitimuojantis „dalinimąsi" vieni kitų kūnais kaip gyvybiniais resursais. Lotyniškai cum panis reiškia „su duona“. Kompanionai - stalo bendrininkai, maisto dalininkai. Pasirinkdama posaki "rūšys kompanionès" rūšių sąveikos (mitybos grandinès) apmąstymams ${ }^{10}$, Haraway nepaiso stalo bendrystès metaforoje slypinčių laisvès ir lygybės prielaidų. Kritikai teigia, kad savo samprotavimais Haraway tik palengvina kelius tolesniam gyvūnų išnaudojimui ir entuziastingomis vizijomis atpalaiduoja mus nuo kaltès jausmo ${ }^{11}$. Religiniai rūšių sugyvenimo vaizdiniai (maistu - gyvenimu besidalijančių kompanionų stalo bendrystė; dèl žmonijos gèrio save aukojančios sesers - laboratorinės žiurkès žygdarbis) stokoja juos daugiau ar mažiau atspindinčių realių (ikūnytų) praktikų. Tad visai suprantama, kad ne visi mokslininkai linkę nekvestionuoti „,valgyk ir būk valgoma(s)“ principo, nematyti akivaizdaus masinio smurto gyvūnų atžvilgiu arba imti ji traktuoti kaip nuolankaus dèkingumo reikalaujančią egzistencinę normą.

Ieškant išeičių iš užburto „valgyti ar nevalgyti“" rato (dažna šiuolaikinių debatų apie žmogaus - gyvūno santykius pabaiga) labai svarbu pamatyti sociokultūrines praktikas, kurios atveria galimybes žmonių ir gyvūnų dialogui ${ }^{12}$. Judith Butler parodè, kad priespauda isiveikia per neapgalvojimo ir neivvardijimo teritoriju steigimus ${ }^{13}$. Siekiant sumažinti tokių teritorijų egzistavimą (kurios ir íveiksmina speciesismą $\left.{ }^{14}\right)$, svarbu apmąstyti praeities ir dabarties sociakultūrines praktikas, liudijančias žmonių sieki suprasti „kitaip kalbančius" gyvūnus bei kurti ,,isiklausymu" gristus sugyvenimo būdus.

\section{GIMINYSTĖ KAIP GYVENIMO SOLIDARUMAS}

Tai palyginti nauja ideja - priešinti gyvūnu ir žmoniu gyvenima...

Gilbert Simondon

Gilbertas Simondonas Dvejose pamokose apie gyvūna ir žmogu pateikia trumpą svarstymų apie žmogaus ir gyvūnijos santykius Vakaru filosofijoje apžvalgą. Šios apžvalgos tikslas - pristatyti savo individuacijos teorija, kuri gyvą individą traktuoja kaip tam tikrai laiko trukmei aplinkos elementus susiejanti procesą. Priešindamas individuaciją tiek asmenybe besiremiančiai monistinei substancialistinei metafizikai, tiek bipoliškumui, kylančiam iš hylomorfizmo, Simondonas dèmesi nuo konstituoto individo (ir iš jo bandomo išvesti individuacijos principo $)^{15}$ perkelia i tapsmą kaip individuacijos apraiška, teigdamas, kad ne iš individo sužinome apie individuacija, bet iš individuacijos - apie individą ${ }^{16}$. Simondonas siekia pateikti kompleksišką ir išsamų individuacijos paaiškinima, pradèdamas fiziniu lygmeniu ir baigdamas psichine ir kolektyvine individuaci- 
jomis $^{17}$. Simondonas Dvejose pamokose apibendrina: Antikos, Viduramžiu ir Renesanso mąstytojai teikia prioritetą žmogaus gyvenimui gyvūnų gyvenimo atžvilgiu, bet tai daro be jokios griežtos ir aistringos opozicijos. Gimstantis dualizmas pasitelkia gyvūną kaip kontrastą žmogui. Gyvūnai traktuojami kaip nežmonès, neprotingi padarai, fiktyvios, pseudo-gyvos būtybès. Kartezianizmas naudojasi gyvūnais kaip idealiai sukonstruotos žmogiškos realybės dublikatais.

Tačiau, Simondono teigimu, būtent skandalingos Dekarto doktrinos išprovokavo toki minties judejjima, kuris tapo palankus mokslinių instinktų ir gyvūnų elgesio teorijų atsiradimui, o galiausiai ir šiuolaikinei žmogaus instinktų teorijai ${ }^{18}$. Šiuolaikiniu požiūriu tai, ką mes atrandame tyrinèdami gyvūnus (instinktyvu gyvenimą brendima, elgesio vystymąsi), leidžia mums apmąstyti žmogiškąją prigimtit ${ }^{19}$. Tokie apmąstymai ittraukia ir socialinę realybę, kurios sandara yra artima gyvūniškam susigrupavimui $^{20}$. Simondono geneologiškai ,,atstatytas" funkcinis paralelizmas ir rūšinis susietumas autoriaus plètojami per individuacijos sąvokos aiškinimą.

Simondono idejjos turèjo įtakos šiuolaikiniams moksliniams diskursams, kuriuose konstituotas individas imamas traktuoti kaip iliuzija, priešinamasi genetiniam ir bet kokiam kitam determinizmui atkreipiant dèmesi i r reiškinių kompleksiškuma, dinamiškuma, interakciškumą ir erdvinę sklaidą. Visi šie procesai regimi kaip specifiški kontekstui ir abipusiškai vienas kitą veikiantys. Šios individuacijos, Simondono terminais kalbant, nusakomos kaip „konkretūs, kū- niški santykiai, laike ir erdvèje integruojantys besivystančių genetinių interakcijų vidinius tinklus su ekologinių interakcijų išoriniais tinklais“"21.

Atrodo, kad kompleksiniams fenomenams šiais laikais nebegalioja paprasti redukcionistiniai paaiškinimai. Nebent santykiai, anot Haraway, gali pasitarnauti kaip mažiausias i̇manomas analizės būdas. Ir nors terminas ,,santykiai“, kurị vartojo Heideggeris ir Merleau-Ponty sąmonès ir pasaulio vienybei nusakyti, kai kurių mąstytojų nuomone, suponuoja gyvų būtybių ir aplinkos atskirumą ${ }^{22}$, šiuolaikiniuose moksliniuose diskursuose jis vartojamas interakcinio pobūdžio vyksmams ir giminingumui nusakyti. Tad ir pati giminiškumą reikètu matyti kaip dalyką visiškai neatsiejamą nuo dinamiško, ìtraukiančio ir darančio ittaką proceso.

"So, make kin, not babies!" - „Darykimès giminèmis, užuot "darę" vaikus!“ ragina Haraway ${ }^{23}$.

Prieš keliant klausimą kaip praktiškai šis raginimas galètų būti igyvendinamas, koks turètų ar galètų būti dinaminis interakcinis procesas, kuriantis tarprūšinius giminiškus santykius, dar kartą sugriž̌kime prie giminingumo sampratos. Haraway priešinasi giminingumo supratimui, siejamam su gimine ir kilme, jam priešstatydama organini bendrumą kaip giminystės pamatą. Tačiau gal yra kitu giminingumo sampratų, kurios būtụ labiau orientuotos i giminingumą skatinantį vyksmą?

Aptardamas Aristotelio funkciju teorija, nurodančią i gyvybinių funkciju paraleliškumą visose gyvybès formose ${ }^{24}$, Simondonas reziumuoja: „Pagal šią teo- 
riją visos rūšys gyvena tuo pačiu būdu. Galima sakyti, visos rūšys gyvena. ${ }^{\prime 25}$ "Jie nori gyventi“", - teigia Donovan, kviesdama įsižiūrèti i aiškiai suprantamą gyvūnų kūno kalbą ${ }^{26}$. Akivaizdu, kad gyvūnus užjaučiantis požiūris yra susijęs ne su tiesiniu - hierarchiniu, žmogu išaukštinančiu pasaulio vaizdu, bet su pasaulèvaizdžiu, kuriame visos gyvos būtybès yra vienos savitarpio ryšiais susietos bendruomenès dalys. Giminystè neatsiejama nuo rūšis įtraukiančio vyksmo. Visi šio vyksmo dalyviai - as- menys ir nežmogiški asmenys - daro itaką vienas kitam, todèl jų veiksmai turi būti atsakingi. Giminingumo kaip gyvenimo solidarumo supratimas suponuoja rūšių interakciją. Tokia giminystė ne „duotybé ${ }^{\text {“27 }}$, bet pasekmé - tarprūšinị susietumą suvokiančios, išgyvenančios ir igyvendinančios bendruomenès veiksmu rezultatas.

Antropologiniai tyrinëjimai pateikia daugybę gyvenimo solidarumu grịstu tarprūšinès sąveikos pavyzdžiu. Keletą iš jų netrukus aptarsime.

\section{SOCIOKULTŪRINIS RŪŠIŲ SUGYVENIMAS}

Leidžiantis ì rūšis suvienijančiu ir tarprūšini dialogą skatinančių socialinių praktikų paiešką, svarbu tarprūšini bendrumo supratimą pradèti sieti ne vien su organiniu, bet su įveiksmintu kūniškumu - giminingumu, kuris kuriamas ir išreiškiamas per judesius ir veiksmus erdvèje. Būtent su bendros erdvès dalinimusi ir judesių, ritmų suderinamumu yra susijęs pirmasis gyvūnu ir žmonių sociokultūrinès sąveikos pavyzdys.

Kristin Armstrong Oma, pasitelkdama Bronzos amžiaus Skandinavijos namų ūkių archeologinius tyrimus, analizuoja kartu gyvenusių žmonių ir prijaukintu gyvūnų gyvenimo ritmą. Kasdieninès sąveikos ir tarpusavio santykiai atsispindi namu ù uikio pastatu architektūroje. Pastatai būdavo padalinti i d dvi dalis (po vienu stogu). Dalinimasis gyvenamąja erdve palengvindavo rūpinimąsi gyvūnais - jiems būdavo lengviau asistuoti sunkiu gimdymų metu, maitinti, prižiūrèti. Tokios kasdieninès praktikos kaip melžimas reikalavo ne tik fizi- nio artumo, bet ir bendro ritmo bei tarpusavio pasitikẻjimo. Ir žmonès, ir gyvūnai turèjo jaustis saugiai vieni kitu akivaizdoje. Namų ūkio išplanavimas liudija pastangas kurti ramią aplinką žmonių ir gyvūnų interakcijai, skatinančią švelnų ir malonu bendravimą kuo daugiau fiziškai susiliečiant ${ }^{28}$.

Amstrong Oma cituoja Knight, teigusị, kad visi kadaise prijaukinti gyvūnai buvo socialaus charakterio. Visgi, prijaukimo procesas kūrè pasitikèjimo santykius, kurie buvo svarbiausias faktorius nerašyto susitarimo, kurị Mary Midgley pavadino socialiniu kontraktu tarp žmogaus ir gyvūno ${ }^{29}$, o Vonne Lund, Raymond Anthony ir Helena Röcklinsberg etiniu kontraktu ${ }^{30}$. Šiuos kontraktinius santykius nusako pasitikejjimu gristas bendradarbiavimas, turintis abipusę naudą - žmonès pasitiki, kad gyvūnai bus paklusnūs ir linkę bendradarbiauti; gyvūnai tikisi, kad žmonès juos gins, maitins ir rūpinsis jais. Rūpinimosi ir bendradarbiavimo praktikas etinio kon- 
trakto gynejai mato kaip vis dar egzistuojančią alternatyvą gyvūnų išnaudojimui. Amstrong Oma, pademonstravusi puoselètų žmonių ir gyvūnų susitikimų svarbą Bronzos amžiuje, teigia, kad tai reikia matyti kaip diskursyvu, santykius formuojanti procesą - sąveikos lauką, kuriamą bendrų veiksmų, atlikimų, susiderinimų. Autorès teigimu, tokie erdviškai modeliuojami susitikimo taškai gali būti labai svarbi archeologinių žmogaus - gyvūno santykių studijų sfera ${ }^{31}$.

Akivaizdu, kad sociokultūrinès praktikos nèra marginali tema keliant klausima, kaip gali būti vystomas dialogas tarp žmonių ir gyvūnų. Nuo erdvès modeliavimo iki judesių, ritmų suderinimo bei šių dalykų svarbos perteikimo kitiems bendruomenès nariams, naudojant menines priemones - toks platus sociokultūrinių praktikų spektras, užfiksuotas antropologiniuose tyrimuose. Šiuolaikinėse kūno studijose taip pat gausu tyrimų, atskleidžiančių naujus (arba senai pamirštus) savęs - kito pažinimo būdus, akcentuojančius proceso dinamiškumą. Atskirties užmiršimas, nuolatinis derinimasis, tapsmas vienu, laikymasis kartu, buvimas tèkmèje, judesyje, abipusiškas susitelkimas i kinestetinius patirties modalumus, sekimas ritminemis komunikacijos formomis, kinetinėmis melodijomis - tai tik dalis įvairių autorių siūlomų sąvokų arba mėginimų ivvardinti dinamiškos žmogaus ir gyvūno sąveikos aspektus $^{32}$. Kaip procesai ar ivykiai traktuojami ir sąveikaujantys kūnai - visuomet neužbaigti, perdaromi aktualių galimybių kontekste. „Kūnas randasi dèka gyvenimo, pasireiškiančio daugialypumu. Kūnas - visada daugiau nei vienas, visuomet aktyvus iškart keliose vienu metu vykstančiose <...> individuacijos

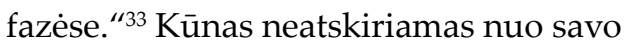
aplinkos, kuri parūpina terpę bei praktikas (kūno ir sociokultūrines), kurios ir leidžia bei suteikia galimybes individualiems ir kolektyviniams kūnams igyti formą arba judèti ${ }^{34}$.

Paulas Shepardas, aprašydamas žmonių ir gyvūnų sugyvenimo ritualus tradicinėse bendruomenėse, pabrèžia sąveikaujančio jautrumo svarbą. Toks jautrumas, puoselejamas per mitus ir kūrinijos stebèjimą per ritminę gyvūnų elgesio imitacija, galiausiai leisdavo priimti sprendimus, pripažistančius neišvengiamą gyvenimo veiksnių ìvairovę. Rūpestis populiacijos, o ne tik individo išlikimu pasireikšdavo "teisę" tapatinant ne tiek su individualios egzistencijos tąsa, kiek su pagarba jai ir suvokimu, kad ir „teisè mirti bei būti prideramai suvalgytam teisingai pripažintoje maisto grandinèje gali atskleisti visų tvarinių teisę i gyvenimą“35. Pagrindinis aktualus tarprūšiniu sugyvenimu besirūpinančiųjų klausimas nėra kas daroma (kertama, valgoma ir t. t.), o kaip daroma. Šis kaip nèra pabėgimas nuo nepatogiu klausimu, o „panirimas" i gyvenimo sudètingumą ir atsakomybès prisièmimas - tikèjimas konkrečiu veiksmų svarba. Kita vertus, tai - jokiais gražiais žodžiais nepamainoma dalyvavimo patirtis. Shepardo teigimu, verbalinè kalba yra visiškai neefektyvi maisto grandinei apibūdinti. Tokiems egzistenciniams tarpusavio santykiams nusakyti reikalinga žymiai gilesnè kalba: neverbalinis, nuo gamtos neatitrūkstantis vyksmas - ritualas.

Shepardas nurodo, kad nykstant gyvūnų rūšims, žmonès išgyvena egzistencinę vienatvę, nerasdami savo vietos 
tarprūšinëje ìvairovèje. Akivaizdu, kad prie egzistencinès krizès labai prisideda sociokultūriniu praktiku, ịprasminančiu tarprūšini sugyvenima, nykimas.Tai atveria kelius ideologinès antropocentrinès vaizduotès įsigalèjimui, apribojančiam kitokias mąstymo apie save pasaulyje galimybes. Maisto grandinei ir rūšių susietumui tampant mokslinėmis abstrakcijomis, tiesiogiai nesusijusiomis su tikrais (iš)gyvenimo pasirinkimais, žiauraus elgesio su gyvūnais (masinio smurto ju atžvilgiu) laukas igauna neribotą suverenitetą.

\section{MENO "GYVŪNIŠKUMAS" IR ŠOKIO YPATINGUMAS PUOSELĖJANT TARPRŪŠINI GIMINIŠKUMĄ}

Šokančio žmogaus būtis yra kaip gyvūno, atsiduodančio fiziniam likimui...

Serge Lifar

Šiame poskyryje aptarsiu meno vaidmeni puoselëjant tarprūšinį dialogą. Kelsiu klausima, kokios meno praktikos gali ypatingai pasitarnauti tarprūšinių santykių kūrimui? Kokios meno teorijos gali paskatinti tokias praktikas ir parodyti ju svarbą?

Shepardo teiginys, kad verbalinè kalba yra visiškai neefektyvi egzistenciniams tarprūšiniams santykiams apibūdinti, ir Donovan kvietimas įsiklausyti i gyvūnų kūno kalbą (kaip homologišką žmogiškam elgesiui) bei kinestetinių patirties modalumų sureikšminimas kūno studijose (tarprūšinès komunikacijos strategiju tyrimuose) ragina naujai pažvelgti į neverbalines menines praktikas. Vienas ryškiausių meninès neverbalinès raiškos fenomenų - šokis.

Šokis - paradigmiškai kūniškas menas, sunkiai telpantis į tradicinès Vakaru estetikos ir meno supratimo rèmus. Pagal dominuojančią estetikos ir meno samprata, neverbalinè raiška buvo siejama su negebejimu artikuliuoti civilizaciniu ypatybiu, kitaip tariant, su necivilizuotumu. Vyraujantis estetikos ir meno supratimas nevertino(-a) meno kūrinio iš dalyvio(-ès) patirties, apsiribojo(-a) žiūrovo žvilgsniu ir meno kūrinį traktavo(-uoja) kaip savitikslį fenomeną. Meno kūrinys, „apvalytas" nuo išorinio pasaulio tikslu, tuo pačiu "apvalomas“ ir nuo socialiniu (tuomet - ir tarprūšinių) santykių. Kita vertus, šokis kaip išraiškos būdas nèra būdingas vien žmonèms, tad pagal tradicinę Vakaru estetikos ir meno samprata, negalèjo bendrai būti laikomas menine raiška, o tik ikimenine ${ }^{36}$.

Tačiau esama meno teoriju, kurios būtent šiuos, dominuojančiu estetiniu požiūriu, marginalius dalykus laiko bet kokios meninès veiklos ištakomis. Ellen Dissanayake pateikia alternatyvią estetikos teoriją - , i rūšis orientuotą" požiūri i mena, nesutikdama su susiaurintu požiūriu i̇ mena, ỉsigalejjusius per pastaruosius du šimtmečius. Ieškodama „,biologinio meno branduolio"ši autore apsistojo prie meno kaip daiktu ir elgsenu "darymo ypatingais" traktuotès, i kurią telpa ir "meno kūrinys", ir bet kuris menas, turejjęs socialinès, kultūrinès ir individualios svarbos vystymuisi ir daręs kažką ypatinga rūšims, visuomenei, kultūrai ${ }^{37}$. Autorès teigimu, standartinis ir 
neišskirtinis gyvuliškas polinkis atskirti iprastą nuo neiprasto, atpažinti ypatinguma, turejo vystytis per dešimtis tūkstančiu metų kartu su kitais aukštesnio lygio pažintiniais gebejimais (tokiais kaip planavimas iš anksto, priežasčių ir ju pasekmiu ivvertinimas).

Pasirinkdama „ypatingumo“ epiteta, Dissanayake nori išryškinti pozityvų rūpesčio ir susirūpinimo faktorių. Ypatingas objektas arba veiksmas apeliuoja i emocinius, o taip pat i percepcinius ir kognityvinius faktorius - t. y. ị visus mūsu protinio funkcionavimo aspektus. Nors šie trys yra neperskiriami, iprasta estetinè nomenklatūra linkusi perdètai pabrèžti tai, kas patenkina atsietas ir abstrakčias intelektualines reikmes, sensorinių, emociniu, fizinių, malonumą teikiančiu reikmių sąskaita. Taigi „ypatingas" nurodo ne tik daikto neiprastumą ir jo sukeltą percepcini poveiki, bet ir patị daryma, randantį būdą, kaip išreikšti pozityvią emocinę vertę.

Dissanayake teorija dera su Elizabeth Grosz „gyvūniška“" meno traktuote. Knygoje Chaosas, teritorija, menas Grosz teigia, kad menas yra gyvūniškas, nes jam priskiriamos kaip tik tos savybès, kurios charakterizuoja gyvūnišką egzistenciją seksualinès atrankos galia, pasireiškianti per vibruojanti gundymą (dèmesio patraukimas, viliojimas, pasirodymas, meilikavimas) ir teritorijos organizavimus ${ }^{38}$. „Menas nèra savitikslè veikla, atskirta nuo gamtinio ir socialinio pasaulių funkcionavimo būdų. Kita vertus, menas nèra nei langas i $\mathfrak{x}$ šiuos pasaulius, nei ju vaizdavimo ar tyrimo metodas, - jis neturètų užsiimti socialinėmis arba politinès analizėmis ar filosofinėmis spekulia- cijomis. Greičiau jis yra tai, kame dauginasi ittampos, kame jẻgos išreiškiamos savo pačiu labui, kame pojūčiai gyvuoja ir eksperimentuoja, kame ateitis yra priartinama per jausmus ir potyrius. <...> Meno kūriniai nẻra ženklai (o jeigu ir yra, tai tik savo pačių); vietoje to, jie sutikrovina pajautimus... ${ }^{\prime 39}$ Meno politiškumą Grozs mato ne meninès veiklos kolektyviškume ar bendruomeniškume, bet nauju galimybiu išlaisvinime, kuris vyksta per atsivėrimą pojūčiams, kurie yra kitokie, nei mums jau pažistami. „Menas yra tai, kame žemės virsmai susijungia su gyvenimo tapsmais ir sukelia įtampas bei pajautimus, galinčius iššaukti kokybiškai naują gyvenimą." Kitaip sakant, meno misija - paruošti kūnus naujiems tapsmams (arba naujoms individuacijos galimybėms) per kūnų atvėrimą naujiems pojūčiams ir nuojautoms. Tai - labai svarbus ateities veikeju igalinimas!

Abi - etologinè Dissanayake meno teorija ir Grozs "gyvūniška" meno traktuotè - meną kildina iš gyvūniškos egzistencijos. Skirtingi šių autorių meno funkciju interpretavimo akcentai yra susiję su ju tyrimų kryptimis - ieškodama "biologinio meno branduolio“, Dissanayake dairosi $\mathfrak{i}$ tolimą praeiti, tuo tarpu Grosz domina meno vaidmuo atveriant ateities gyvenimo galimybes. Abi šios teorijos akcentuoja dalyvavimo patirti, socialinių santykiu svarbą ir gali būti taikomos tarprūšinės sąveikos kontekste. Siekdama įrodyti teigini, kad sociokultūrinès judesio ir šokio praktikos gali ypatingu būdu prisidèti prie tarprūšinio dialogo skatinimo ir etiškesnių santykiu (at)kūrimo, panagrinėsiu kelis šokio meno pavyzdžius, pasiremdama 
šiomis teorijomis. Dissanayke teoriją pritaikysiu pristatydama sociokultūrinių šokio praktikų reikšmę tarprūšinei sąveikai tradicinejje visuomeneje, Grosz meno traktuotę - aptardama šiuolaikinius šokio meno pavyzdžius.

Paulas Shepardas pateikia pavyzdžių, kaip ypatingai būdavo formuojami (pasinaudojant Dissanayake posakiu) tarprūšiniai santykiai. Nuo gyvūnų elgesio pamėgžiojimo vaikystėje iki metafizinio zoomorfinio îkūnytumo, išgyvenamo šokyje. Tokios praktikos sudarydavo prielaidas ne tik giliai suvokti tarprūšini gimininguma, bet ir išvystyti unikalų šio patyrimo būdą - stilių, charakterizuojantị atskirą bendruomenę ir suteikianti asmeniui priklausomybès tai bendruomenei pojūtit ${ }^{40}$.

Kalbėdamas apie šokio praktikas kaip inspiruojančias tarprūšinio giminingumo apmąstymus, Shepardas akcentuoja judesio ir judèjimo būdų kūrimą erdvèje, neatsiejamą nuo laiko tèkmès įsisąmoninimo. Šokis persirengus gyvūnais - su paukščių plunksnomis arba gyvūnų kaukèmis - demonstruodavo žmogaus sielos plastiškuma, gebejimą keisti formą laiko nulemtose socialinèse arba kosmoso transformacijose bei primindavo globèjišką gyvūnų vaidmenị. Pastarieji buvo regimi kaip svarbiausių gyvenimo paslapčiuc - virsmo, gimimo, brandos, išgydymo, piršlybų, vaisingumo, apsaugos - sergètojai ir perteikejjai. Galima teigti, kad šokis sukurdavo terpe ypatingam laiko (egzistencijos metafora) išgyvenimui. Per dalyvavimą îvairius kūnus itraukiančiame judesio vyksme dalyviai galèjo pasijusti didesnio egzistencinio virsmo dalimi ir tuo pat metu aktualiai išgyventi savo konkrečių veiksmų reikšmingumą (per solidarumo, sąveikos su kitais, psichofizinių ir simbolinių mainų svarbos vyksmo sklandumui išgyvenimą). Trumpai tariant, bendruomeninis šokis aktualizuodavo sinergiją ir „ypatingus padarydavo" visų gyvų būtybių tarpusavio santykius.

Ar yra šiuolaikinių šokio pavyzdžių, skatinančių tarprūšinio giminingumo apmąstymus? Gabrielè Brandstetter, apžvelgdama gyvūnų vaizdavimą XIXXX a. Vakaru šokyje, konatatuoja, kad gyvūnų vaizdavimas visų pirma pasitarnavo kaip priemonè, atverianti pačio šokio kaip judesio meno ypatumus. Pasitelkiant gyvūnų vaizdinius buvo atvertos žmogiškumo dimensijos. Jų spektras labai platus - nuo orumo kūnui sugrąžinimo (poetiškas gulbès vaizdavimas) iki iš-kūrimo šiuolaikiniuose performansuose (juose gyvūnas nebėra trokštamo kūniškumo simbolis, bet politinès, „nužmoginančios" situacijos simptomas arba susitikimas su pačia konkrečiausia kūno materija ${ }^{41}$, parodančia atropocentrizmo iliuzijos išvirkščią pusę). Panašus „,apvertimas" vyksta ir pačio šokio kaip medijos plotmèje - pasitelkiant gyvūnų ir paukščių vaizdinius, pats kūnas ir judesys igyja centrinę vietą - judesys išlaisvinamas, pabrèžiamas judesio tèkmès aspektas, akcentuojamas kinestetinis judesio prièmimas ${ }^{42}$, nereikalaujantis papildomo dvasinio-naratyvinio paaiškinimo. Žvelgiant iš tarprūšinės sąveikos pavyzdžių paieškos pozicijos, visi Brandstetter minimi pavyzdžiai (Mariaus Petipo „Gulbių ežeras", Mikhailo Fokino "Mirštanti gulbè“, Merce'o Cunningham'o „Pajūrio paukščiai“, Elsos Deceukelier perfor- 
mansas su dvidešimčia kačių ir kt.) gali liudyti tarprūšinių santykių ilgesi. Vis dèlto pristatyti juos kaip šiuolaikinius rūšis integruojančių sociokultūrinių praktikų pavyzdžius ar bandymus įsiklausyti i homologiška žmogiškajai kūno kalba kalbančius gyvūnus būtų netikslu.

Erika Fischer-Lichte, aprašydama gyvūnų naudojimą šiuolaikiniame teatro ir performanso mene, taip pat akcentuoja gyvūnų atveriamus performatyvumo aspektus - ivykiškuma, energetiškuma, „buvimą“43. Kūnas (aktoriaus, o ypač gyvūno) kaip medija tokiuose pasirodymuose patiriamas kaip ivykis, o abieju rūšių kūnų buvimas kartu ilgainiui atskleidžia nykstanti skirtumą tarp žmogaus ir gyvūno. Nors ir naudojamas žmogaus patirčiai, „buvimui“ atverti, pats gyvūnas greičiau yra komunikuojamos „analogijos“ įrankis, o ne kuriamų tarprūšinių santykių bendradarbis.

Tačiau sugrižkime prie Brandstetter paminètų Merce'o Cunninghamo „Pajūrio paukščių“44. Šis kūrinys nepretenduoja atskleisti tiesos apie žmonių ir gyvūnų koegzistavimą. Pasak choreografo, visų jo kūrinių vienintelè tiesa yra pats šokis - tiesiogiai patiriamas vyksmas. Juose nerasime gyvūnų judesių pamėgdžiojimo, nerasime ir užuominų apie bendrą "gyvūniškumą". Net Cunninghamo šokio technikos mokyme nèra jokio "gyvūniško" prieskonio, būdingo kitoms judesio technikoms ${ }^{45}$, - dauguma judesių atliekami stovint, pratimai ittraukia visą kūną, stiprina ir mobilizuoja kiekvieną jo dali. Choreografas dèmesi skiria savitai judesio artikuliacijai, ritmui bei judejjimui erdvèje $e^{46}$. Tačiau tiek šokèjai, tiek žiūrovai, pasakodami, kaip juos paveikė Cunninghamo trupės šokis, liudija kažką panašaus i tai, ką Serge'as Lifaras pavadino ,atsidavimu fiziniam likimui“ (žr. citatą poskyrio viršuje). Ypatingas gyvumas (patiriamas šokejjų), percepcinis atgyjimas (patiriamas žiūrovų) kalba apie šio choreografo ypatingą gebejjimą kurti meno kūrinius, kurie, grižtant prie Grosz išsakytų minčių, atveria kūnus naujiems pojūčiams, o šiuo konkrečiu atveju - naujoms gyvumo dimensijoms. Šių gyvumo dimensijų atradimas, patyrimas artina prie kitų gyvu būtybių žymiai labiau, nei gyvūnų ar žmonių kūnų vertimas meninėmis ,priemonėmis" ar ideologinès tiesos ženklais. Meno kūrinyje, tokiame kaip Cunninghamo „Pajūrio paukščiai“, sutikrovintas fizinis gyvybingumas - per šokyje išreikštą šokejjų atsidavimą judesiui ir erdvei - ruošia žiūrovą percepciškai angažuotis. Šis kvietimas atsiverti pasauliui judesyje ittraukia ir jautrų dėmesingumą aplinkai - ritmams, erdvei, daiktams, bei ìsiklausymą i kitų gyvų būtybių atsivèrimus per judesi.

Pasinaudodama šiuo Cunninghamo kūrybos pavyzdžiu, noriu išryškinti šokio vaidmeni skatinant tarprūšinį dialogą. Anot Dissanayake, menas yra daiktų ir dalykų darymas ypatingais. Šokis ypatingais padaro gyvuma, judrumą ir sugyvenimą judèjimą kartu. Šių dalykų padarymas ypatingais mene, jei seksime Grosz ižvalgomis, turètų ypatingu būdu paruošti (percepciškai sužadinti) kūnus sąmoningai priimti savo ir kitų gyvų būtybių gyvumą bei igalinti pasitikti naują gyvenimo būda, kuriame tarprūšinis kinetinis atidumas vaidins svarbų vaidmeni. 
Koks tai bus (su)gyvenimo būdas galime tik spèlioti. Tačiau antropologiniai ir semiotiniai tyrimai byloja apie aktualiai išgyvenamų tarprūšinių santykių itaką tarpžmogiškų santykių raidai. Neretai tarprūšinių santykių modeliai tapdavę idealiais bei sektinais modeliais žmonių bendruomenèms. Straipsni pabaigsiu šios prielaidos iliustracija.

Algirdas Julius Greimas knygoje Lietuviu mitologijos studijos aptaria bičiulystès sampratos sąsajas su socialine struktūra, kilusia iš socialinio kontrakto (žr. poskyrị „,Sociokultūrinis rūšių sugyvenimas") tarp žmonių ir bičių. Pagalbinès giminystès institucijos - užkurystè, žentystè, įsodina - mitinèje plotmèje atitiko bitininkavimu sudaromų santykių modelit, o šis turèjo aiškias nuorodas i etinio kontrakto tarp žmonių ir bičių specifiką ${ }^{47}$. Greimas ši nerašytą susitarimą vadina moraliniu arba bičiulystès kodeksu, grịs- tu socialinio glaudumo (bendradarbiavimo laisva valia) ir gero sugyvenimo (atvirumo, svetingumo, kaimyninio solidarumo) principais. Bitininkystè negalëjo būti giminystès įrankiu - priemone susirasti sau žmona, ,ji siekia visų pirma susibičiuliavimo, o jau tarp žmonių, tapusių „giminėmis nuo bičių“, lengvai atsirenkami ir būsimi žentai“" ${ }^{\prime 4}$. Greimas pateikia elgesio su bitèmis pavyzdžius, kylančius iš bičiulystès kodekso paisymo. Konkrečiuose veiksmuose ir sociokultūrinèse praktikose įūnytas žmonių ir bičių solidarumas ilgainiui tampa žmogiškų santykių idealu. Etinis tarprūšinių santykių dèmuo, „išskleistas“ per dainas ir šokius, kloja žmonių bendruomenės sugyvenimo pamatą. Giminystès randasi ant šio pamato kaip susibičiuliavimo „„šokio“ (kūnu sąveikos erdvëje) pasekmè.

Gal tokia ir yra sociokultūrinès bendrystės tarp žmogaus ir gyvūno evoliucija?

\section{IŠVADOS}

Josephine Donovan pasiūlyta dialoginė prieiga nagrinèti žmogaus - gyvūno santykius atkreipia dèmesi i gyvūnų kūno kalbą (homologišką žmogiškam elgesiui) - svarbų galimo tarprūšinio dialogo dèmenį. Donna Haraway rūpesčio etikos epicentru laiko gimininguma, siejamą ne su šeima ar kilme, bet su visų gyvų būtybiu organiniu ir genealoginiu bendrumu. Simondono individuacijos sąvoka, aiškinama žmogaus - gyvūno santykių kontekste, atveria tarprūšinès sąveikos dinamiškumą ir veda prie interaktyviais veiksmais kuriamo ir formuojamo giminystès supratimo. Visos šios teorinès prielaidos legitimuoja archeologiniu duomenų, patvirtinančių žmonių ir gyvūnų bendrumo suvokimo bei socialinio sugyvenimo siekius, paieškas. Straipsnyje pateikiami antropologiniai tyrinejjimai atskleidžia ne tik tokių praktikų specifiką bei svarbą tarprūšiniam sugyvenimui, bet ir fakta, kad sociokultūrinėse praktikose ikūnytas ne žodžiais išreikštas „socialinis kontraktas" arba etinis įsipareigojimas tarp žmogaus ir gyvūno kartais tapdavo idealiu tarpžmogiškų santykių modeliu (liudija lietuviško žodžio „bičiulystè" epistemologija).

Praeityje šokis buvo sociokultūrinè žmogaus - gyvūno giminystès asimiliacijos (per judesį ir judèjimo būdų kūrimą 
erdveje) praktika. Gyvūnų vaizdavimas šiuolaikiniame šokyje susijęs su žmogiškumo dimensijų atvèrimu ir kinestetinio patyrimo atgimimu šokio medijos plotmejje. Ellen Dissanayake ,i rūšis orientuotas" požiūris į meną kartu su Eliza-

\section{Literatūra ir nuorodos}

${ }^{1}$ Lyn Mikel Brown ir Carol Gilligan, Meeting at the crossroads: Women's psychology and girls' development. Feminism \& Psychology 3.1 (1993): 11-35, p. 15.

2 Josephine Donovan, Feminism and the treatment of animals: From care to dialogue. Signs 31.2 (2006): 305-329, p. 307.

${ }^{3}$ Gilligan Carol, In a different voice. Harvard University Press, 1982, p. 19.

${ }^{4}$ Donovan, pritardama Nel Noddings, teigia, kad, jeigu gailestingumo praktikų būtų sistemingai mokoma kaip dalyko mokyklose, jos taptu visuotinai įtvirtintu moraliniu sprendimu prièmimo pagrindu ir nebepriklausytu nuo įvairiu individualių nuomonių bei igeidžių (Donovan Josephine, The feminist care tradition in animal ethics: A reader. Columbia University Press, 2007, p. 309).

${ }^{5}$ Josephine Donovan, Feminism and the treatment of animals: From care to dialogue. Signs 31.2 (2006): 305-329, p. 307, p. 310.

6 Ten pat, p. 317.

7 Donna J. Haraway, When species meet. Vol. 224. U of Minnesota Press, 2008, p. 36.

${ }^{8}$ Donna J. Haraway, Anthropocene, capitalocene, plantationocene, chthulucene: Making kin. Environmental Humanities 6.1 (2015): 159-165, p. 162.

9 Donna J. Haraway, When species meet. Vol. 224. U of Minnesota Press, 2008, p. 36.

10 Tokie apmąstymai, anot autorès, sujaukia visą (žmones rūšiuojančių) kategorijų pasaulį. Donna J. Haraway, When species meet. Vol. 224. U of Minnesota Press, 2008, p. 19.

11 Weisberg Zipporah, The broken promises of monsters: Haraway, animals and the humanist legacy. Journal for Critical Animal Studies 7.2 (2009): 22-62, p. 48, 53.

12 Pagaliau juk valgymas (arba ėdimas) nèra vienintelis (su)gyvenimo sinonimas! Ypatingus beth Grosz "gyvūniška" meno traktuote padeda išryškinti žmonėms ir gyvūnams būdingo "gyvumo" suestetinimą šokio mene ir suteikia pagrindą prielaidai, kad ir ateityje tarprūšinis sugyvenimas gali būti „daromas ypatingas".

žmonių ir gyvūnų santykius nulèmę tarpusavio mainai irgi neapsiriboja vien maisto teikimu. Tad tai neturètų būti vienintelè rūšis suvienijanti praktika.

13 Judith Butler, Imitation and Gender Insubordination. Lesbian and Gay Studies Reader. (Ed.) Abelove H., Barale M. A., Halperin D. M. New York: Routledge, 1993, 307-320. Print, p. 312.

14 Speciesismas (speciesim) - nepakantumas arba diskriminacija rūšiniu pagrindu, pasireiškianti žmonių žiaurumu gyvūnams arba jų eksploatacija (prieiga per internetą: $<\mathrm{http} / / / \mathrm{w} w w . t h e f-$ reedictionary.com/Specieism>).

15 Gilbert Simondon, The genesis of the individual. Incorporations 6 (1992): 296-319, p. 297.

16 Vollrath Chad, Becoming Analogical. 10 Longing for Lehman Sisters (2009): 42, p. 44.

17 Aislinn O'Donnell, Gilbert Simondon, Two Lessons on Animal and Man, trans. Drew S. Burk. Reviewed by. Philosophy in Review 33.5 (2013): 406-409, p. 406.

18 Gilbert Simondon, Two Lessons on Animal and Man. Minneapolis, MN: Univocal, 2011, p. 60.

19 Simondono požiūriu, toks požiūris nèra vien kartezianizmo apvertimas. Tezè, antitezè, sintezè - tokią minties raidą Vakarų filosofijoje nagrinèjant žmogaus - gyvūno santykius pastebi mąstytojas. Šiuolaikinis diskursas pateikia sintetinį požiūrì, kuris iš naujo patvirtina žmogaus ir gyvūno artimuma, kartu atskleisdamas kiekvienos rūšies ypatumus.

20 Toks požiūris, anot Simondono, leidžia apsvarstyti tam tikrus socialiniu santykių modelius (pavyzdžiui, dominavimo, viršenybės) žmoniu giminèje.

${ }^{21}$ William. J. Grassie, Eating Well Together: Donna Haraway's Companion Species Manifesto. Metanexus Global Spiral (2009), p. 238, prieiga per internetą: <http://grassie.net/articles/2008_ eating_well_together.html>. 
22 Hubert L. Dreyfus, Foucault's critique of psychiatric medicine. Journal of Medicine and Philosophy 12.4 (1987): 311-333, p. 322.

23 Donna J. Haraway, Anthropocene, capitalocene, plantationocene, chthulucene: Making kin. Environmental Humanities 6.1 (2015): 159-165, p. 162.

${ }^{24}$ Analogiškos funkcijos pasiekiamos kiekvienai rūšiai būdingais, skirtingais būdais.

25 Gilbert Simondon, Two Lessons on Animal and Man. Minneapolis, MN: Univocal, 2011, p. 51.

${ }^{26}$ Josephine Donovan, Feminism and the treatment of animals: From care to dialogue. Signs 31.2 (2006): 305-329, p. 307, p. 315.

27 Nei kilmès „duotybe்“, nei organinè „duotybe்".

28 Oma Kristin Armstrong, Between trust and domination: social contracts between humans and animals. World archaeology 42.2 (2010): 175-187, p. 182.

${ }^{29}$ Mary Midgley, The solitary self: Darwin and the selfish gene. Routledge, 2014.

${ }^{30}$ Lund Vonne, Anthony Raymond ir Röcklinsberg Helena, Journal of Agricultural and Environmental Ethics (2004) 17: 23

31 Oma Kristin Armstrong, Between trust and domination: social contracts between humans and animals. World archaeology 42.2 (2010): 175-187, p. 180 .

32 Blackman Lisa ir Venn Couze, Affect. Body \& Society 16.1 (2010): 7-28.

33 Erin Manning, Always more than one: The collectivity of a life. Body \& Society 16.1 (2010): 117-127, p. 120.

${ }^{34}$ Lisa Blackman ir Venn Couze, Affect. Body $\mathcal{E}$ Society 16.1 (2010): 7-28, p. 21.

35 Paul Shepard ir Jack Turner, Traces of an Omnivore. Island Press, 2006, p. 18.

36 „Gyvūnai irgi šoka!" - teigia mokslo populiarinimo straipsnių ir filmuku antraštès. Pavyzdžiai, kurie ši teigini iliustruoja, dažniausiai būna susiję su individualaus sutvèrimo neiprastais gebejimais judinti letenas, kedenti ar iš- skleisti plunksnas, keistai trypčioti, šokinèti ir t. t. Sumanūs, tikslingi kolektyviniai judèjimo būdai (pavyzdžiui, tūkstantinio žuvų būrio sinchronizuoti judesiai, itin sudètingi, dèmesi blaškantys ir plěšrūną gluminantys manevrai) nelaikomi šokiu. Šis karikatūriškas pavyzdys iš mokslo populiarinimo srities primena įsigalëjusi požiūrị i mena/šokị - kaip i̇ atsietą nuo tikslu pasaulyje, daugiau individualias savybes atskleidžiančią veiklą, ir iš dalies paaiškina, kodèl šiuolaikiniame mene sunku rasti $\mathfrak{i}$ tarprūšinį dialogą ir sugyvenimą orientuoto meno pavyzdžių.

37 Dissanayake Ellen, „The Core of Art-Making Special." Journal of the Canadian Association for Curriculum studies 1.2 (2003), p. 29.

38 Grosz Elizabeth A., Chaos, territory, art: Deleuze and the framing of the earth. Columbia University Press, 2008, p. 69.

39 Ten pat, p. $78-79$.

40 Shepard Paul ir Jack Turner, Traces of an Omnivore. Island Press, 2006, p. 6.

41 Г. Брандштеттер, „Движения животных“: образы животных и воплощение в современном танце. Новое открытие эмоций. Чувство, тело, движение. Кристоф Вульф и Валерий Савчук (ред.). Москва: Канон+, 2011, с. 62-79, 77.

42 Ten pat, p. 73-74.

${ }^{43}$ Erika Fischer-Lichte, Performatyvumo estetika. Vilnius: Menu spaustuvė, 2013, p. 175.

44 Merce'o Cunninghamo „Pajūrio paukščius“ galima pamatyti filmuotoje šokio versijoje „Beach Birds for Camera" (prieiga per internetą: http:// dancecapsules.mercecunningham.org/overview. cfm?capid=46030).

45 Pvz., butoh, jogoje ir kt.

46 Diehl Ingo (sud.). Dance techniques 2010 Tanzplan Germany. Leipzig: Henschel, 2011.

47 Algirdas Julius Greimas, Lietuviu mitologijos studijos. Vilnius: Baltos lankos, 2005, p. 267.

48 Ten pat, p. 266. 